Article

\title{
Sustainable Downtown Development for the Tsunami-Prepared Urban Revitalization of Regional Coastal Cities
}

\author{
Takumi Ito ${ }^{1, *}$, Tsuyoshi Setoguchi ${ }^{2}$, Takashi Miyauchi ${ }^{1}$, Akira Ishii ${ }^{3}$ and Norihiro Watanabe ${ }^{2}$ \\ 1 Division of Architectural and Structural Design, Graduate School of Engineering, Hokkaido University, \\ Sapporo, Hokkaido 060-8628, Japan; t.miyauti@ictech-jp.com \\ 2 Division of Architectural and Structural Design, Faculty of Engineering, Hokkaido University, Sapporo, \\ Hokkaido 060-8628, Japan; setoro@eng.hokudai.ac.jp (T.S.); n-watanabe@eng.hokudai.ac.jp (N.W.) \\ 3 Northern Regional Building Research Institute, Hokkaido Research Organization, Asahikawa, \\ Hokkaido 078-8801, Japan; ishii-akira@hro.or.jp \\ * Correspondence: takumi19940404@gmail.com; Tel.: +81-11-706-6243
}

Received: 27 December 2018; Accepted: 12 February 2019; Published: 15 February 2019

\begin{abstract}
Regional cities in Japan are facing a decline in the downtown area owing to urban expansion and a decrease in the population. Promoting downtown living is indispensable for the realization of downtown revitalization. Since many coastal cities originally developed outward from a port, their downtown areas are located near the coast and are at high risk of tsunamis. The purpose of this research is to reveal the effectiveness of dealing with the above two issues in parallel by evaluating the Deae-ru Saiwai estate, a public housing relocation project in downtown Kushiro, Hokkaido, Japan that incorporates a tsunami evacuation facility with questionnaires and a GIS survey. Placing public housing in the downtown area shortens the distance to public facilities and improves the convenience of the surrounding environment for many residents. Installing the tsunami evacuation facility improves the feeling of reassurance of residents who would feel anxiety about immigration with regards to tsunamis. This research has clarified the synergistic effect of dealing with the daily and emergency issues in parallel for promoting downtown living. Planning downtown revitalization and disaster prevention concurrently, which has been separated so far, is a fundamental planning approach for urban revitalization in regional coastal cities.
\end{abstract}

Keywords: urban revitalization; downtown living; tsunami; public housing; coastal cities

\section{Introduction}

The achievement of sustainable urban development in the face of a declining population is a global issue in urban planning. Population decline is a common and serious problem in many developed cities around the world. In recent years, a declining birthrate and an aging population in Japan have made its population decline particularly serious. The population of Japan began to decline from 128.06 million in 2010 and it is estimated to drop to less than 100 million in 2048 [1]. Japan's declining population foreshadows the situation in other developed countries in the coming decades. The population decline is exacerbated in regional cities due to population movements to large cities that offer advantages in terms of convenience, school attendance, and employment, on top of the overall chronic population decline and declining birthrate [2]. In Hokkaido, the northernmost prefecture of Japan, the population decline has outpaced that of the rest of Japan by 10 years [3]. Therefore, the implementation of sustainable urban development that is capable of catering to a declining population is particularly required in this prefecture. 
Urban expansion is one of the most serious problems in many countries, including both developed and developing countries. In Japan, urban expansion began with an increase in the population after the war since the 1960s. Even then, the city continued to expand owing to the motorization, road improvements in the suburbs, the placing of large-scale shops and the relocation of public facilities to the suburbs and cheaper residential land than in the downtown area. Urban expansion has induced various problems globally. Erosion in the agricultural land $[4,5]$ and an increase in the greenhouse gas and $\mathrm{CO}_{2}$ emissions [6,7], urban public services expenditure [8], and travel costs [9] have been experienced globally. Especially in Japan, a decrease in the downtown population due to the population decline and population outflow to big cities has resulted in a higher population density in vast urban areas, lower than in the expanded cities. The low density and vast urban area not only caused high maintenance expenses but also a decline in convenience [10].

Expansion in cities results in a decline in the downtown area. In Japan, the decline in the downtown area is mainly caused by the out-migration of the residents, reducing the exchange population and the withdrawal of commercial facilities such as retail stores due to the expansion of cities. The outflow in population is caused by the change in the lifestyle of residents with regards to convenience that does not depend on the location and on living in large detached housing due to motorization and road improvement, high land prices and a lower level of convenience in the downtown area due to the relocation of commercial facilities and public facilities to the suburbs [11]. The commercial facilities in the downtown area are withdrawn due to the large commercial facilities that attract customers and are located in suburban areas [12]. A decline in the downtown area, as well as urban expansion, has several problems. There is an increase in vacant houses and crime [13], an inefficiency of the existing infrastructure [14], and a loss in stable tax sources [15]. Since 2000, owing to the low convenience and increased maintenance expenses, local governments are aiming at consolidating expanded and low-density urban areas [16]. Under this policy, the downtown area is expected to play a vital role, such as work, commerce, education, and welfare, among others, in consolidated cities. From this viewpoint, the decline in the downtown area is a serious problem.

The downtown revitalization aims to overcome the abovementioned two major problems $[17,18]$. Downtown revitalization is to reintegrate centripetal forces of the downtown area by realizing a city with a high convenience for everyday living and the aggregation of residential and public facilities. This approach can suppress urban expansion and the decline in the downtown area and lead to the downsizing of the urban area. Methods for downtown revitalization are being studied globally. There are commercial activation [12] and tourism and the culture-led revitalization [19,20]. In Japan, the important factor contributing to downtown revitalization is an increase in the resident population. It is also possible to stimulate the increase in the population due to the commercial activation of the positive correlation between the population density and the sales value in the downtown area. For this reason, downtown living is particularly promoted as a means of downtown revitalization in Japan [21]. This is a plan to introduce the population to the downtown area from the suburbs by placing residential and public facilities in the downtown area. Common challenges in the promotion of downtown living are securing a convenient everyday life and cheap and high-quality housings.

In inducing the movement of residences and public facilities to the downtown area, local governments are particularly promoting public housing relocation [21]. This is because public housing is both a residential facility and a policy-controllable facility. Public housing planning is one of the most important strategies for promoting downtown living. In other words, the relocation of public housing contributes to the realization of downtown revitalization in Japan. Research into public housing planning often discusses the habitability of this safety net for low-income earners. Galster and Hesser [22] and Riazi and Emami [23] evaluated satisfaction with public housing, while Mu and Szumien [24] and Morris et al. [25] considered the improvement of the community within public housing through social mixing. In addition, Tam et al. [26] developed a universal design guide for handrails focusing on the needs of the elderly in public housing. However, there has been little research into the utilization of public housing for urban restructuring such as in downtown revitalization. 
In regional cities in Japan, local governments are promoting the integration of various public facilities to reduce fiscal burdens and maintain existing services [27]. It is similarly necessary to consider the possibility of complex public facilities in public housing. In this way, public housing can play a further role in the realization of downtown revitalization. Complexing of public facilities in public housing can thus be seen as a tool for solving regional problems. In Hokkaido, a project was carried out in which a childcare facility was incorporated into public housing [28]. This project was aimed at improving the child-rearing environment in the downtown area to promote the inflow of households which have children into the downtown area. It is thought that public housing relocation can contribute not only to the building of sufficient-quality housings in the downtown area but also to the improvement of the convenience of everyday life, i.e., to solve problems for the promotion of downtown living. However, the effect of this measure on the living environment in the surrounding urban areas has not been revealed. To explore the possibility that public housing can foster downtown revitalization, it is important to clarify the effect of such measures on the problems.

Several large-scale tsunami-related disasters have occurred in recent years, especially in island countries. The Indonesian tsunami in 2004 affected more than 10 countries and killed about 300,000 people [29]. In the Tohoku earthquake of 2011, the tsunami water reached more than $5 \mathrm{~km}$ inland in some areas, reaching a maximum of $19.5 \mathrm{~m}$ above sea level [30]. The eventual death toll was 15,641, with an additional 5007 people declared missing. After the 2011 Tohoku tsunami, it has become necessary to produce estimates and countermeasures for the largest earthquakes and tsunamis that may occur in every coastal area of Japan [31]. The largest earthquakes and tsunamis predicted based on seismology threaten several coastal areas of Japan such as the Nankai Trough area [32]. As the urban areas of many coastal cities have developed through port development [33], their central urban areas are located near the coast and are at high risk of tsunami damage.

Two types of measures are taken against tsunami disasters in coastal cities. The first is to relocate the urban area to a higher ground. In the course of rehabilitation planning, some local governments of areas that suffered tsunami disaster in the 2011 Tohoku Tsunami relocated urban areas to hills. However, this prolonged the period for which evacuees had to live at their evacuation destination because too much time was required to acquire land and carry out construction [34]. Consequently, fewer residents returned to the new urban areas than expected, and there was a lot of unused land. Depending on the environment of the relocation destination, this kind of resettlement can have a negative influence on the livelihood of the relocated households [35]. In addition, since the relocation of the urban area expands the city area, it could lead to an increase in the maintenance cost of urban facilities. The above indicates that relocation planning is not realistic as a response to tsunami disasters in coastal cities. Therefore, planning to reduce the risk of tsunami disasters while maintaining the existing downtown area is an important issue for local governments in coastal cities.

Thus, the second type of tsunami-mitigation measure is the construction of tsunami evacuation buildings in coastal downtown areas. This is being carried out in many coastal cities and has been identified as the main strategy used in order to reduce disaster risk and conduct safe urban development [36,37]. These tsunami evacuation buildings are generally tall and are constructed with high seismic, wave and fire tolerances [38-41]. However, most tsunami evacuation buildings in Japan have been designated as evacuation facilities for existing high-rise buildings [42]. A total of 1790 buildings in Japan were designated as evacuation facilities in 2009; however, this increased to 3986 after the 2011 Tohoku tsunami [43]. The existing high-rise buildings do not have structural reinforcements or sufficient equipment; therefore, such buildings are not good enough.

The above reveals that local governments in regional coastal cities in Japan have a dilemma: they want to promote downtown living to realize downtown revitalization, but there is a high risk of tsunami damage in downtown areas. Therefore, it is necessary for regional coastal cities to respond in parallel to the two tasks of the promotion of downtown living and tsunami prevention for downtown revitalization. However, most of the current urban development in these cities only cover one of these tasks. The Deae-ru Saiwai estate project deals with the promotion of downtown living and the 
improvement of tsunami evacuation performance together. The purpose of this paper is to clarify the necessity and effects of dealing with the promotion of downtown living and the improvement of tsunami evacuation performance in parallel to downtown revitalization in regional coastal cities by evaluating the Deae-ru Saiwai estate project.

\section{Materials and Methods}

There are two issues, namely, the downtown revitalization and tsunami prevention for the urban revitalization, in the regional coastal city. This study uses a program at Deae-ru Saiwai Estate in Kushiro city, Hokkaido as its case study. It is the relocation of public housing to the downtown area with a tsunami evacuation facility. This paper aims to clarify the necessity and effects of dealing with the promotion of downtown living and the improvement of tsunami evacuation performance in parallel in regional coastal cities by evaluating the Deae-ru Saiwai estate project.

\subsection{Overview of Kushiro City}

Kushiro city is located in the eastern part of Hokkaido (Figure 1). It is a core coastal city and faces the Pacific Ocean. Kushiro city has airports and harbors and plays a leading role in the comprehensive development of the eastern part of Hokkaido in terms of administration, commerce and operations, medical and welfare services, education, and culture. The logistics function of the Kushiro Port plays a particularly important role that extends to the Okhotsk area and the Tokachi area. In addition, Kushiro city has magnificent natural attractions such as the Kushiro Wetland National Park, Akan National Park, forests, lakes, and the Pacific Ocean, which is one of the most beautiful natural environments in Hokkaido. The population of Kushiro city peaked at 227,234 in 1980. Since then the population decline has progressed and the population is expected to reach 106,088 in 2040, less than half its peak (Figure 2). The composition of the population is also changing as the proportion of elderly people increases and that of young people decreases. Like other Japanese regional cities, a past increase in the population of Kushiro city caused the urban area to expand from the downtown area to the suburbs. Even as the population began to decline, the expansion of urban areas did not stop, and there was also an outflow of people seeking convenience, school attendance opportunities and employment opportunities of larger Hokkaido cities such as Sapporo city and Asahikawa city. Consequently, Kushiro city has become an inefficient urban area with a low-density population distributed over sprawled urban areas. This low population density and urban sprawl is not only an inconvenience for the residents but also inefficient in terms of urban infrastructure, which has significant maintenance costs. So, the local government has promoted downtown living. It is necessary for the promotion of downtown living to introduce residential and public facilities to the downtown area.

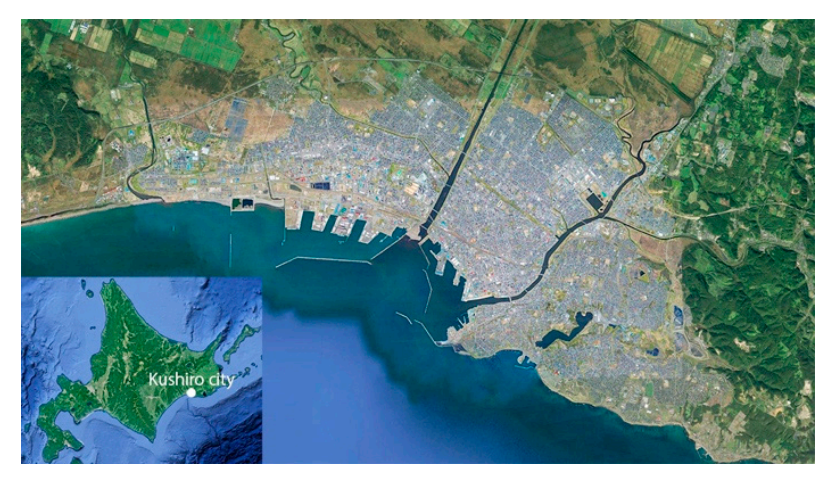

Figure 1. Kushiro city. 


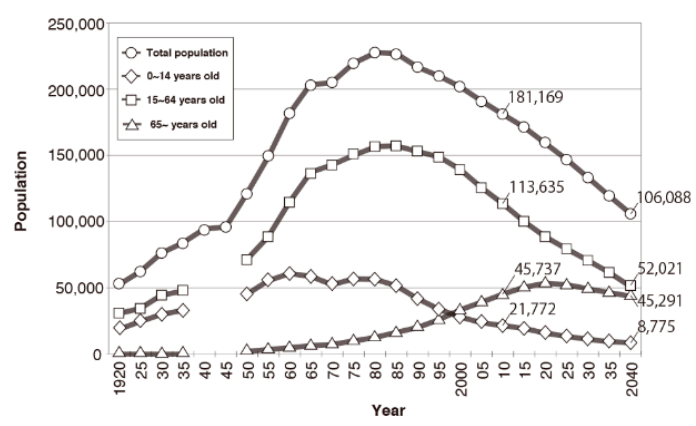

Figure 2. The population changes in Kushiro city.

\subsection{Risks of Tsunamis in the Downtown Area}

The occurrence of the Tohoku tsunami in 2011 and the flood prediction map for the largest class of tsunami make it clear that the downtown area of Kushiro is at high risk of tsunami damage, as can be seen from the combination of these data in Figure 3. Most of the downtown area is predicted to be flooded to a depth of $5 \mathrm{~m}$ to $10 \mathrm{~m}$ or more. The time from the occurrence of the earthquake to the arrival of the tsunami in the downtown area is $30 \mathrm{~min}$. Since the evacuation would start $10 \mathrm{~min}$ after the earthquake occurs, the actual time available for evacuation is $20 \mathrm{~min}$ [29]. Based on this, the distance over which it is possible to evacuate on foot is $1032 \mathrm{~m}$, assuming a walking speed of $0.86 \mathrm{~m} / \mathrm{s}$, which is reasonable for the winter period when there may be snow cover. When adopting a walking speed of $0.5 \mathrm{~m} / \mathrm{s}$, which is more suitable for vulnerable people (those with difficulty walking or physical disabilities, infants, seriously ill people, etc.), this figure comes down to $500 \mathrm{~m}$. Figure 4 shows the $500 \mathrm{~m}$ and $1000 \mathrm{~m}$ ranges in terms of the road distance from the evacuation completion point without being in danger from the tsunami flooding along the evacuation route. This figure indicates that it is difficult to evacuate from the main part of the downtown area to the evacuation completion point within the time available for evacuation. The local government has been promoting the construction of new public facilities with good tsunami evacuation performance and the designation of existing private high-rise buildings as tsunami evacuation facilities in the downtown area (Figure 5). In Figure 5, tsunami emergency shelter refers to a structure that is resilient to tsunamis and has evacuation space indoors. A tsunami evacuation building is a building to which people can temporarily evacuate when escape is delayed; its performance as an evacuation facility is low. The above shows that, similar to other regional coastal cities, Kushiro city has the dilemma that while it is necessary to promote downtown living for the realization of downtown revitalization, the downtown area is at high risk from tsunamis. 


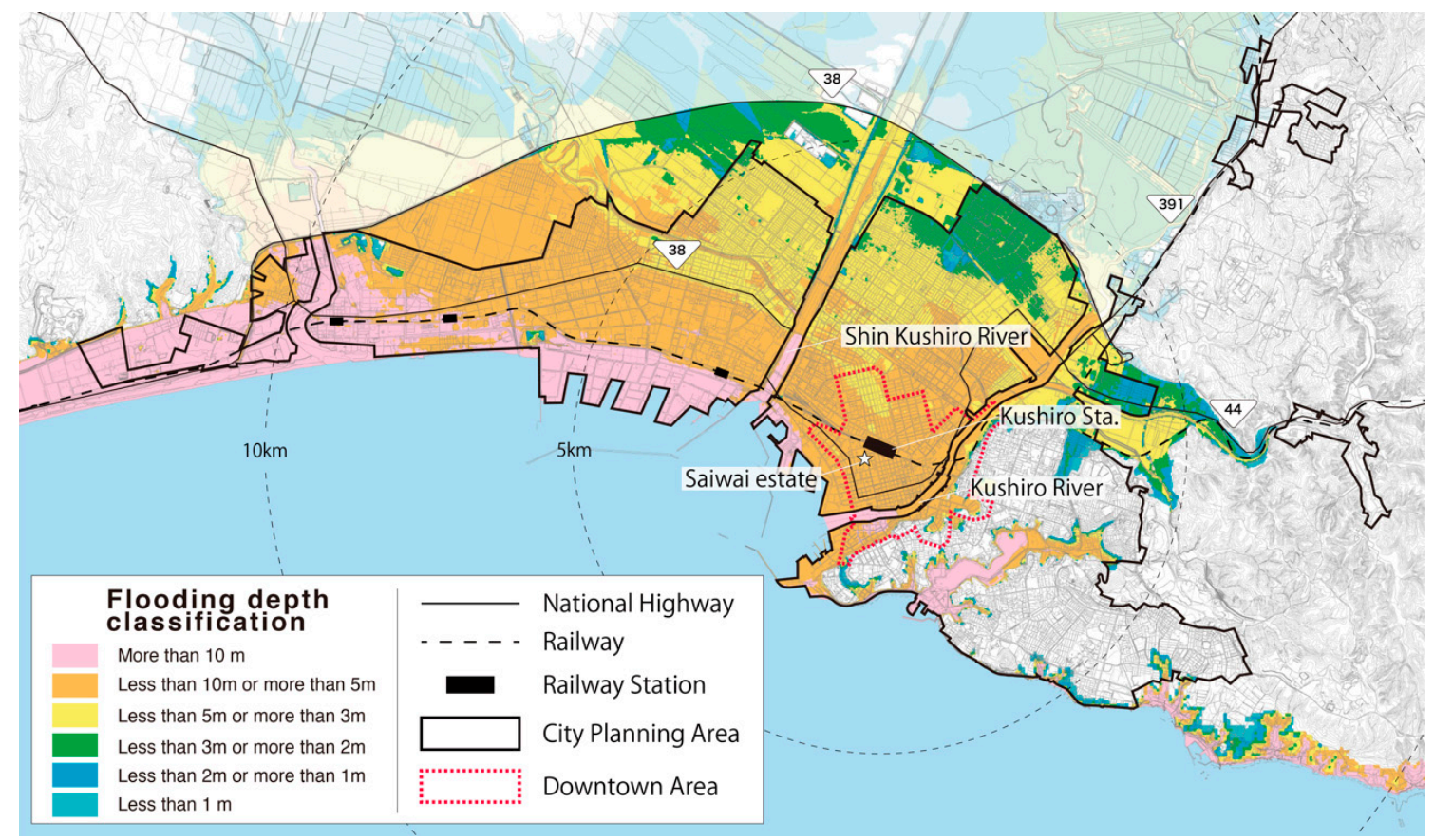

Figure 3. The urban structure and tsunami inundation forecast in Kushiro city.

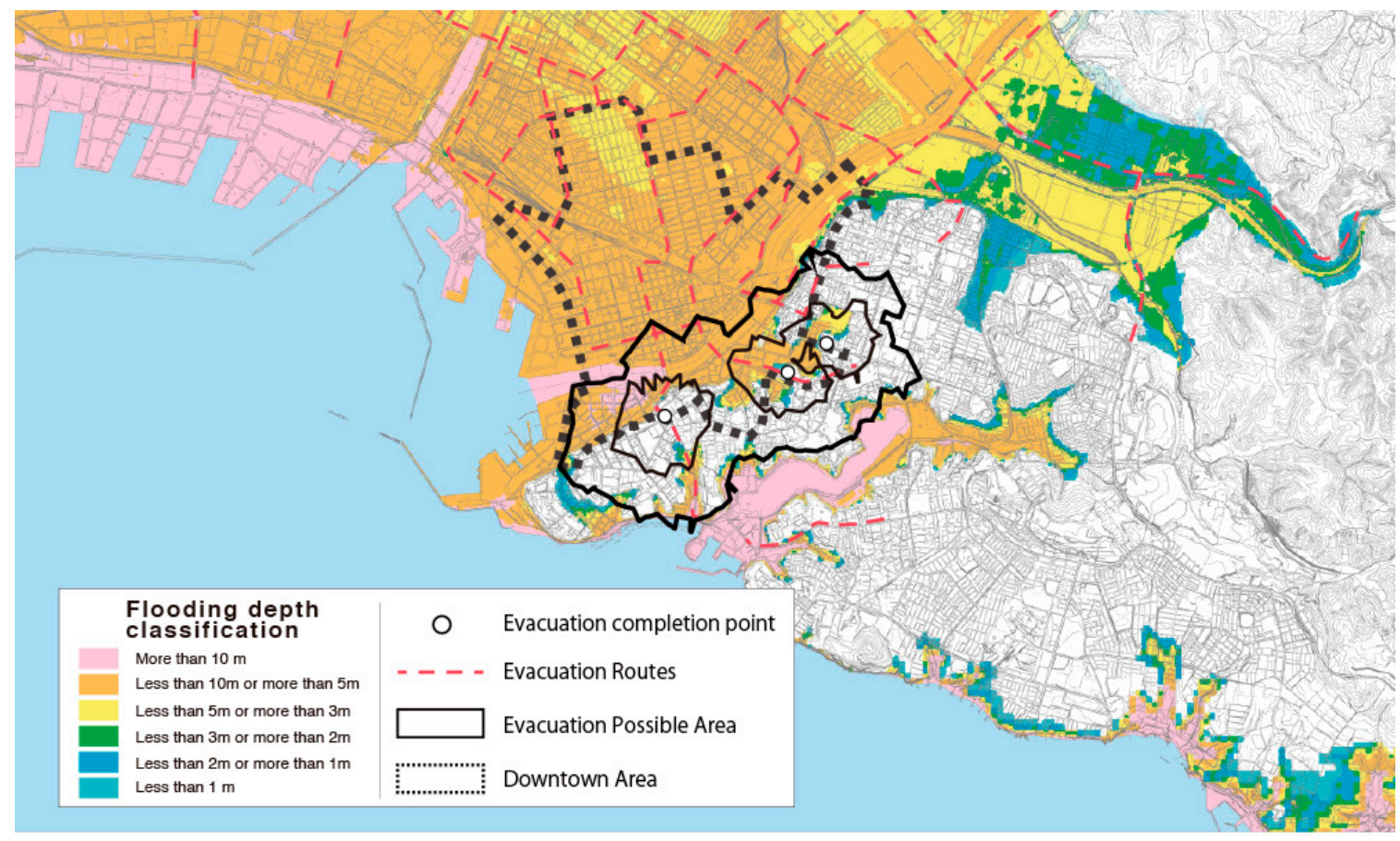

Figure 4. The area from which it is possible to evacuate to a higher elevation $(500 \mathrm{~m}, 1 \mathrm{~km})$. 


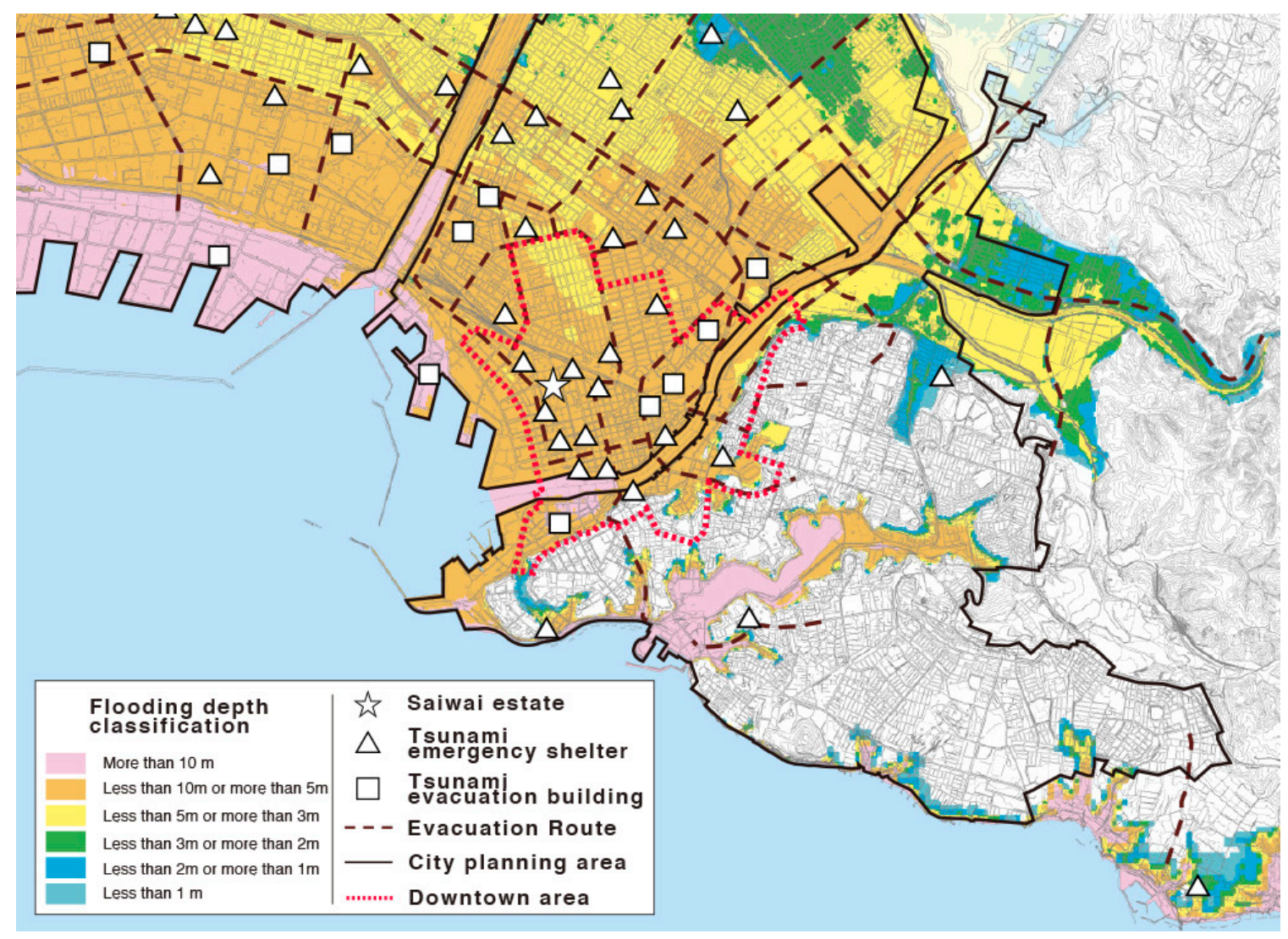

Figure 5. The evacuation facility locations in the downtown area.

\subsection{The Deae-ru Saiwai Estate: Public Housing with Tsunami Evacuation Facilities}

The Deae-ru project has relocated aging public housing in the suburbs to the downtown area, incorporating public facilities corresponding to the issues of the downtown area. The Deae-ru Saiwai estate has been relocated as part of this project and a tsunami evacuation facility has been incorporated into it in order to contribute to the tsunami evacuation measures of the downtown area (Figure 6). The site is near the Japan Rail (JR) station, and a market, post office, elementary school, and nursery school are located in the surrounding area (Figure 7). It comprises 40 units. A total of 15 of these are child-rearing support units, which are only available as residences for households which have young children. The residential units are installed only on the second floor or above in consideration of tsunami flooding. Since the first floor of the building would ward off the impact of the tsunami, it has been designed as a warehouse and bicycle parking facility, with no walls other than those necessary for construction. Emergency power supplies, stockpiles, rooftop hovering space, and evacuation spaces are installed on the top floor (Figure 8). The top-floor evacuation space is planned to be used as a meeting place for residents and as a childcare facility at normal times; however, it becomes a temporary evacuation facility in the event of a disaster (Figure 9). Should a disaster occur, about 1000 refugees can evacuate to evacuation spaces including shared corridors from the $4^{\text {th }}$ floor upwards. The estimated inundation height near the site in the event of the largest predicted tsunami is $6.2 \mathrm{~m}$. Comparing the tsunami inundation level in their former residences to the tsunami inundation level in the surrounding area of the Saiwai estate, it can be seen that most residents have been relocated to an area with a higher tsunami inundation level (Figure 10). This reflects the fact that most of the households moving to the downtown area are facing living with the risk of an increased danger of tsunami flooding. For this reason, to promote downtown living, it is important to reduce the psychological burden imposed by moving to the downtown area by improving citizens' reassurance that adequate tsunami evacuation measures are in place. 


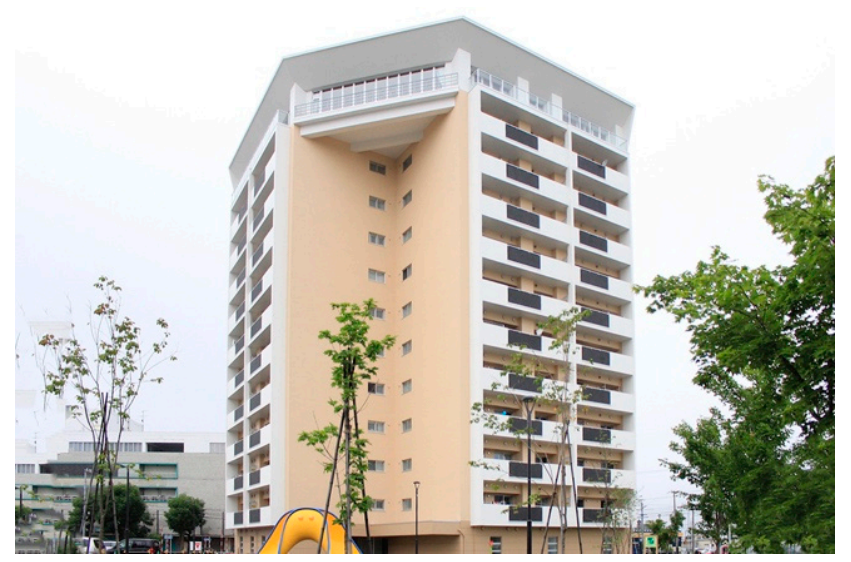

Figure 6. The Deae-ru Saiwai estate.

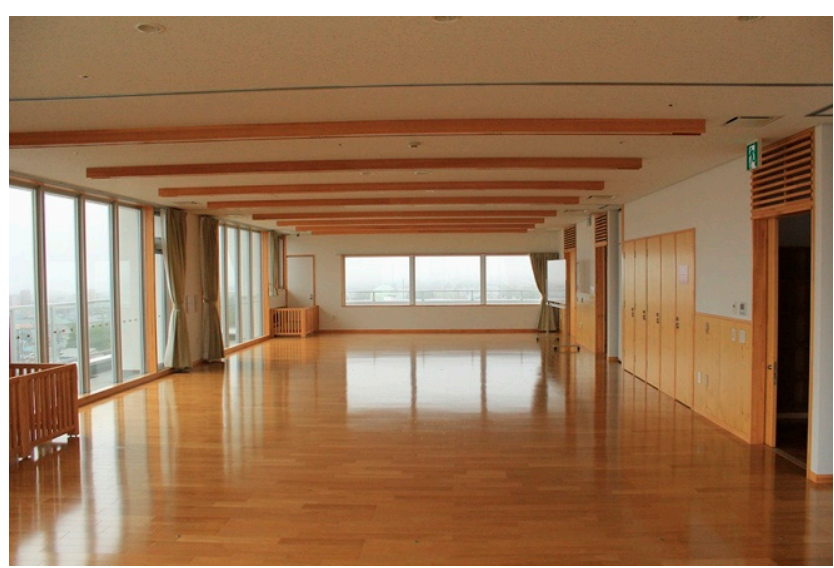

Figure 7. The evacuation space and meeting place.

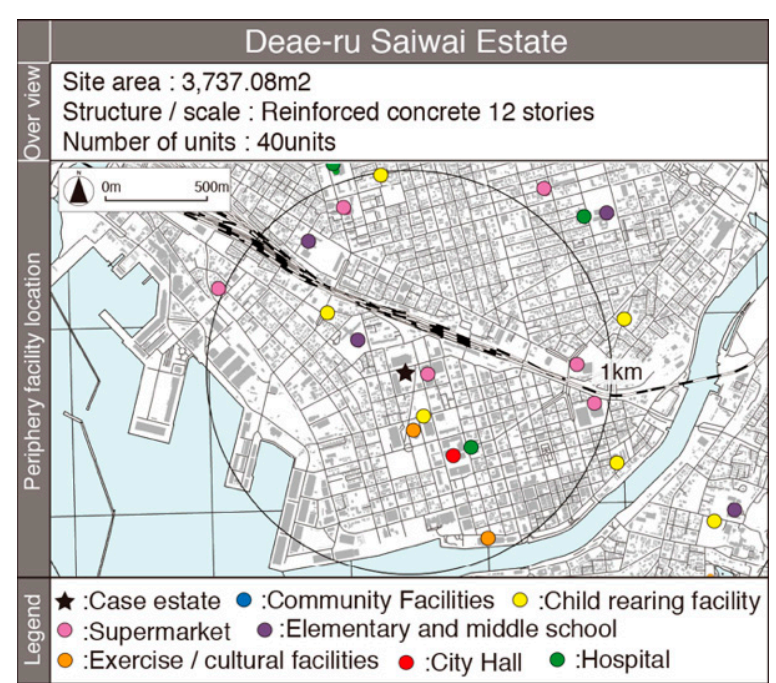

Figure 8. The location of the estate. 


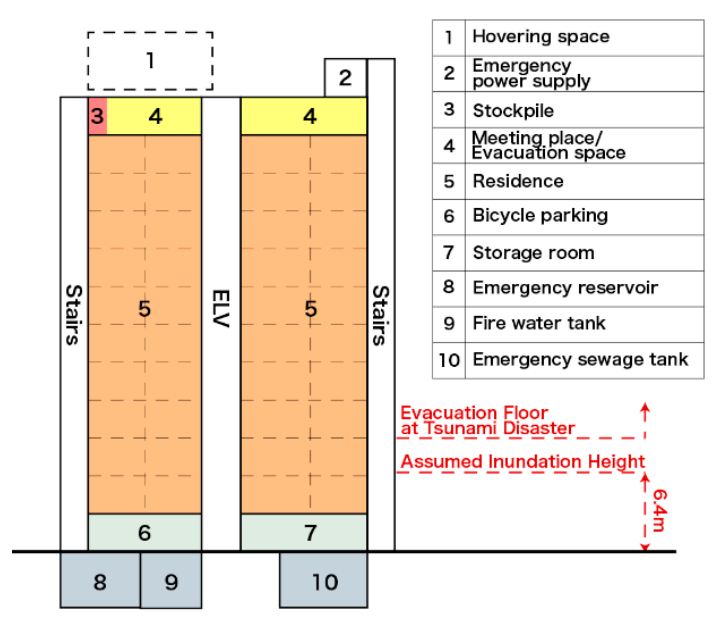

Figure 9. The composition of the estate.

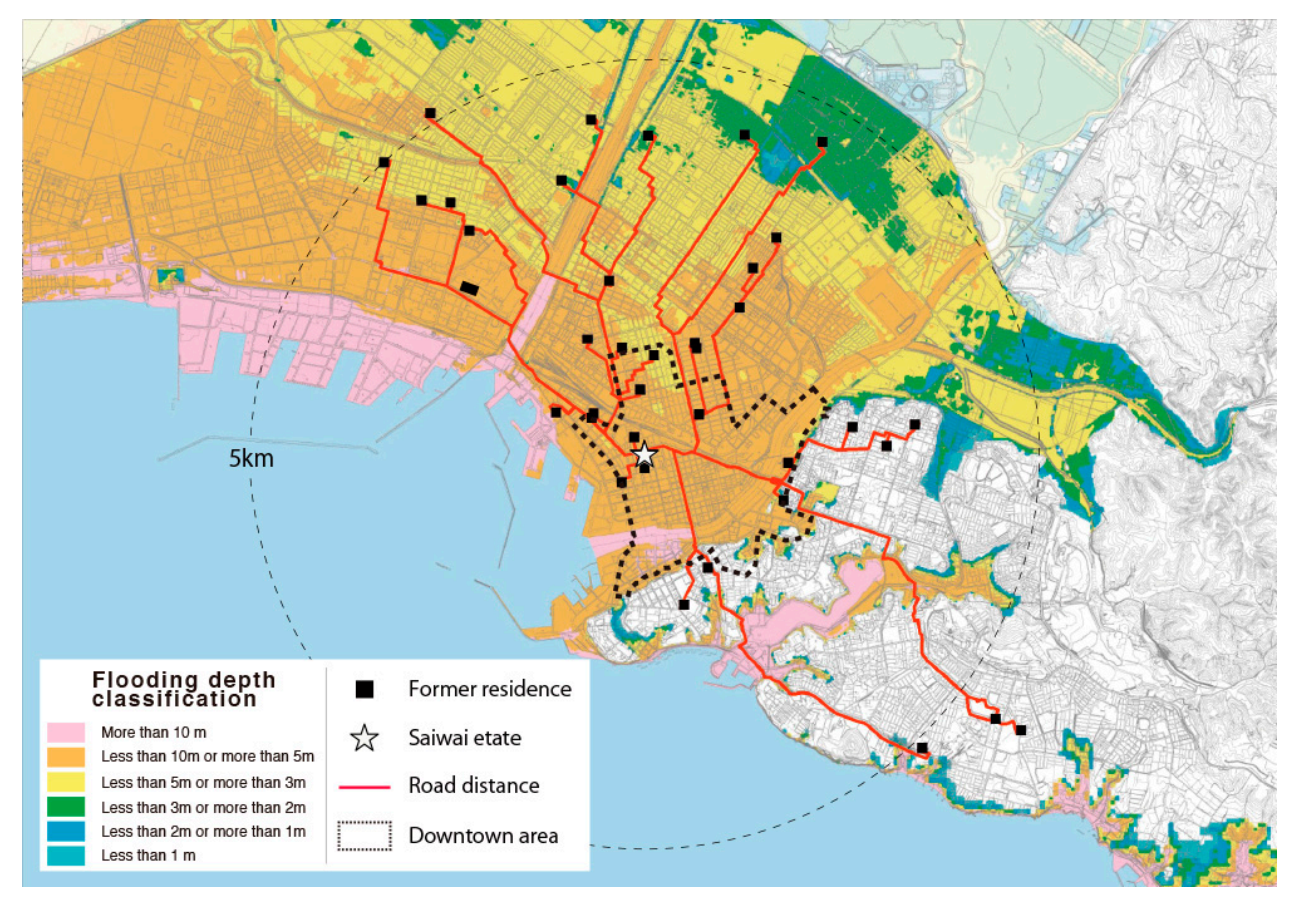

Figure 10. Former addresses of residents.

\subsection{Evaluation Methods for the Saiwai Estate (Table 1)}

As organized in the introduction, this paper aims to clarify the necessity and effects of dealing with the promotion of downtown living and the improvement of tsunami evacuation performance in parallel in the regional coastal cities by evaluating the Deae-ru Saiwai estate project.

In this study, four surveys, A, B, C, and D, were conducted to investigate the Saiwai estate program from two methodical viewpoints: (1) as a survey of people from public housing relocated to the downtown areas and (2) as a survey of the people installed from tsunami evacuation facility to public housing (Table 1). Additionally, the effects of the estate were organized from two viewpoints of evaluation: (1) its effect on the promotion of downtown living and (2) its effect on the improvement of tsunami evacuation performance. The former effect is evaluated by survey A-1, A-2, D-1, and D-2. Survey A was conducted to clarify the effect on the everyday-life convenience of residents due to living in the downtown area. Survey D was conducted to clarify the effect on citizens' reassurance regarding the tsunami evacuation of residents due to the construction of the estate. The latter effect is evaluated using survey B and C. Survey B was conducted to clarify the effect on the recognition of the 
estate as an evacuation facility due to installing a tsunami evacuation facility to the public housing. Survey $\mathrm{C}$ was conducted to clarify the effect on the reduction of the shortest evacuation distance due to the construction of the estate.

Table 1. The evaluation methods for the Saiwai estate.

\begin{tabular}{|c|c|c|c|c|}
\hline & & & \multicolumn{2}{|c|}{ Viewpoints of Evaluation } \\
\hline & & & $\begin{array}{l}\text { Effects on the Promotion of } \\
\text { Downtown Living }\end{array}$ & $\begin{array}{c}\text { Effects on the Improvement } \\
\text { of Tsunami Evacuation } \\
\text { Performance }\end{array}$ \\
\hline \multirow{4}{*}{$\begin{array}{l}\text { Viewpoints of } \\
\text { Method }\end{array}$} & \multirow{2}{*}{$\begin{array}{l}\text { Placing public } \\
\text { housing in the } \\
\text { downtown area }\end{array}$} & Qualitative survey & $\begin{array}{l}\text { [survey A-1] the effect on the } \\
\text { everyday life convenience of } \\
\text { residents due to living in the } \\
\text { downtown area }\end{array}$ & $\begin{array}{l}\text { [survey B] the effect on the } \\
\text { usability of the estate as an } \\
\text { evacuation facility due to } \\
\text { installing a tsunami } \\
\text { evacuation facility in the } \\
\text { public housing }\end{array}$ \\
\hline & & $\begin{array}{l}\text { Quantitative } \\
\text { survey }\end{array}$ & $\begin{array}{l}\text { [survey A-2] the effect on the } \\
\text { everyday life convenience of } \\
\text { residents due to living in the } \\
\text { downtown area }\end{array}$ & \\
\hline & \multirow{2}{*}{$\begin{array}{l}\text { Installing a } \\
\text { tsunami } \\
\text { evacuation facility } \\
\text { to the estate }\end{array}$} & Qualitative survey & $\begin{array}{l}\text { [survey D-1 and D-2] the effect } \\
\text { on the reassurance regarding } \\
\text { tsunami evacuation of } \\
\text { residents due to the } \\
\text { construction of the estate }\end{array}$ & \\
\hline & & $\begin{array}{l}\text { Quantitative } \\
\text { survey }\end{array}$ & & $\begin{array}{l}\text { [survey C] the effect on the } \\
\text { reduction of the shortest } \\
\text { evacuation distance due to the } \\
\text { construction of the estate }\end{array}$ \\
\hline
\end{tabular}

The detailed investigation method is as follows. Survey A-1, a questionnaire survey of estate residents, was conducted to clarify the effect of moving there with regards to their satisfaction with the convenience of their surrounding area (number of target households: 38 ; collection rate: $61 \%$; implementation period: 7 October 2016, to 10 October 2016). Though downtown living is being promoted in some regional cities in Japan, the concrete effect of living there on the living environment has not been clarified. Numerous studies have shown that high accessibility to public facilities is related to residents' satisfaction with their surroundings when living in a city [44,45]. Among the effects of moving on the living environment, this research article especially clarifies the improvement of accessibility to public facilities (Supermarkets, Hospitals, City Halls, Childcare facilities, Cultural facilities, Exercise facilities, Elementary schools, Middle schools and Commuting facilities). As well as questions evaluating residents' general satisfaction with the surrounding environment, questions were set to evaluate their satisfaction with concrete items in the surrounding environment such as the accessibility to public facilities and public transportation, security, and the liveliness of the area. In survey A-2, the distances by road from the estate and from their former residences to public facilities were analyzed and compared to quantify the effect of downtown living on convenience. It also compared the corresponding annual gasoline costs because Kushiro city is one of the leading areas for automobile ownership in Hokkaido. The questionnaire survey showed that about $80 \%$ of residents in the estate own one or more cars, and $25 \%$ own two or more cars. Therefore, the comparative gasoline cost has a large effect on their household finances. Survey B, a questionnaire survey of the surrounding residents, was conducted to clarify the effect on the usability of the estate as a tsunami evacuation facility due to installing an evacuation space in a public facility (target household number: 721, number of responding households: 194, implementation period: 21 October-4 November 2016). The questionnaire was set to evaluate awareness of the evacuation facility in the Saiwai estate and the recognition of the evacuation destination by candidates. Based on the coverage area of each evacuation facility set by the local government, the target is the residents who live in the entire city block in the covered area of the Saiwai estate [46] (Figure 11). Survey C was conducted to clarify the effect of building an estate with a tsunami evacuation facility on the shortest evacuation distance of the surrounding residents. For the total number of residents in the surrounding area, this survey took the 
daytime population (data from 2015). This number was adopted because the area around the Saiwai estate has a larger population during the daytime than during the nighttime. This discrepancy arises because public facilities such as Japanese-style commercial markets and the central post office, and educational facilities such as junior high schools and nursery schools are all present in the surrounding area. Based on the coverage area that the local government sets for each evacuation facility, the target area is the whole city block in the covered area of the Saiwai estate [46]. The evacuation starting point was set as the midpoint of the closest side of each block to the nearest evacuation facility. The evacuation completion point was set as the closest point to the entrance of the evacuation facility on the side of the city block where the evacuation facility is located. In the evacuation distance measurement, the evacuation distance generally includes the distance to climb up to a height where there is no possibility of tsunami flooding in the evacuation facility $[47,48]$. However, in the case of this study, it is unnecessary to consider the traveling time inside the building for the following three reasons. First, it is clear that residents can evacuate to the nearest evacuation facility within the evacuable time (20 $\mathrm{min}$ ) because all the blocks within the scope of the survey belong to the coverage area of the evacuation facilities. There is no point in clarifying the evacuation distance correctly. Second, this survey focused on changes in the evacuation distance before and after the construction of the estate. The travel time inside the building does not affect these changes. Third, the estimated inundation height is the same in all of the places within this investigation range; therefore, even if the nearest evacuation destination changes to the Saiwai estate, the travel time inside the building does not change. Survey D, a questionnaire survey of residents in and around the estate, was conducted to clarify the effect on the feeling of reassurance regarding tsunamis with regards to the incorporation of a tsunami evacuation facility into the Saiwai estate. Kawakami and Asano [49] showed the necessity for evaluating the feeling of reassurance that disaster prevention projects give to citizens. Survey D- 1 is a questionnaire survey of residents (target households: 38 , collection rate: $61 \%$, implementation period: 7 October 2016, to 21 October 2016). The questionnaire items are set to evaluate worries regarding tsunamis that arise from downtown living and the feeling of reassurance provided by living in the Saiwai estate with its tsunami evacuation facility. They are also set to evaluate the issues that contribute to this feeling of security or anxiety about the estate with regards to tsunami evacuation. Survey D-2 is a questionnaire survey of residents in the surrounding neighborhood (target household number: 721, number of responding households: 194, implementation period: 21 October 2016, to 4 November 2016). The questionnaire items were set to evaluate the same items as Survey D- 1 did. The target is the same as in Survey B.

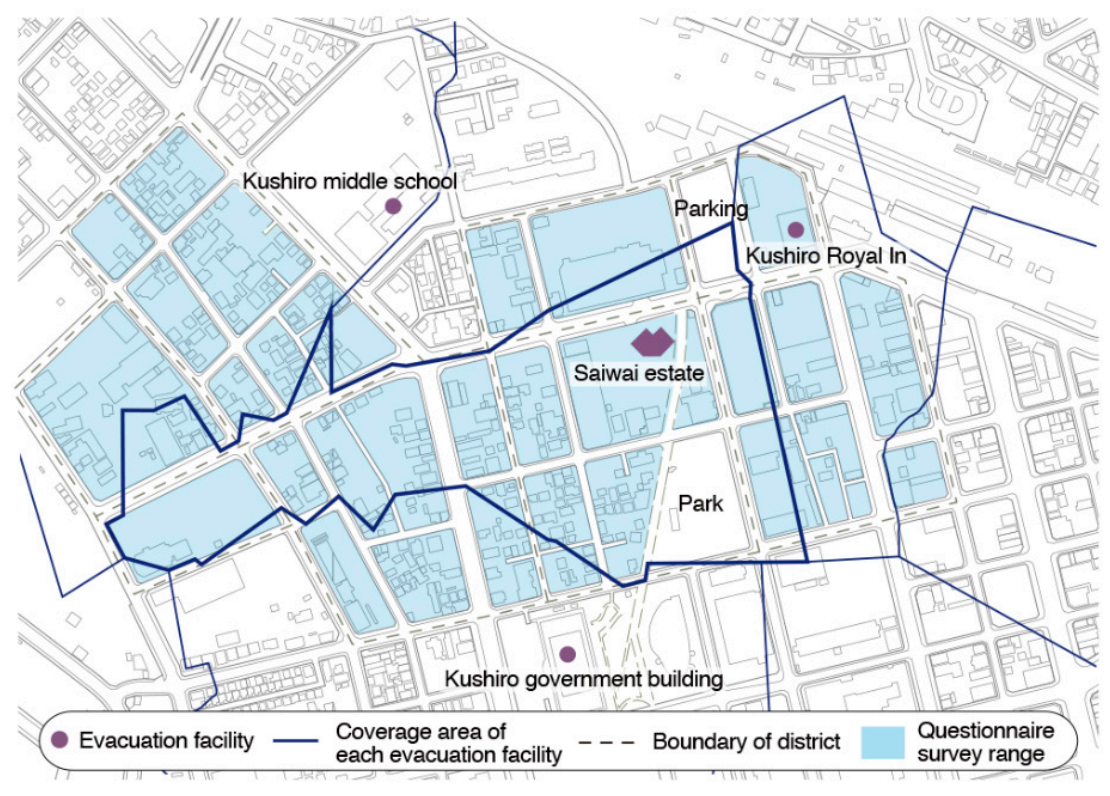

Figure 11. The questionnaire survey range. 


\section{Results}

\section{1. [Survey A] The Questionnaire Survey for Residents of the Estate}

Figure 12 shows the results of survey A. Regarding "satisfaction with surrounding areas," more than $60 \%$ of residents answered "satisfied" or "somewhat satisfied." Regarding "convenience of the surrounding area," nearly $60 \%$ of residents answered "convenient" or "somewhat convenient." More than half of the residents answered "satisfied" or "somewhat satisfied" for items other than "distances to facilities suitable for daily shopping" and "distances to sports/cultural facilities" and "liveliness of the city" in "satisfaction with particular items in the surrounding area."

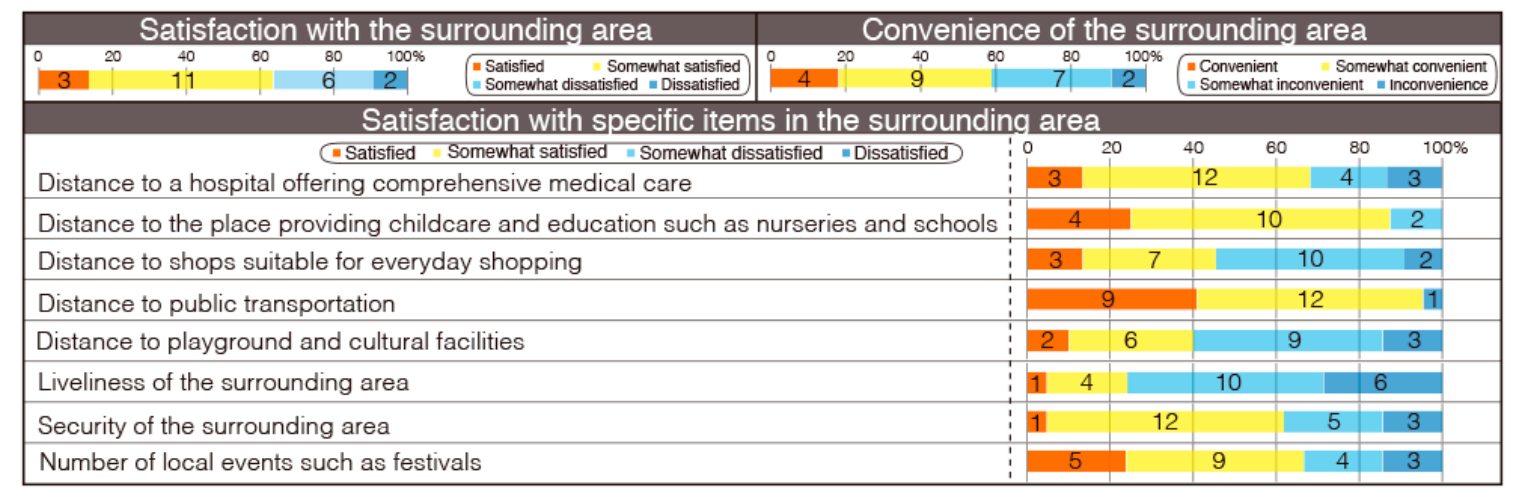

Figure 12. The questionnaire on the resident evaluation of the surrounding environment.

\section{2. [Survey A-2] Change in Commuting Distance and Distance to Public Facilities after Moving}

Figure 13 and Table 2 show the results of survey B. On average, the distance to locations other than "sports facilities" and "junior high school" has decreased. The reduction of the distances to a "supermarket," "nursery school/kindergarten," "sports facility" and for their commute has the effect of reducing the household gasoline cost by more than 10,000 yen per year. Interestingly, while the distance to a supermarket decreased, a low level of satisfaction was reported with "distance to shops suitable for everyday shopping." The comments from residents in the questionnaire's free entry column indicate that this contradiction arose for the following two reasons. First, in the Japanese trading market next to the estate, the price of everyday goods is higher than in supermarkets in general. Second, a large supermarket next to the estate closed shortly after the construction of the housing estate. This result shows that, even in the downtown area, a decline in living convenience can occur if hollowing out causes a withdrawal of public facilities. 


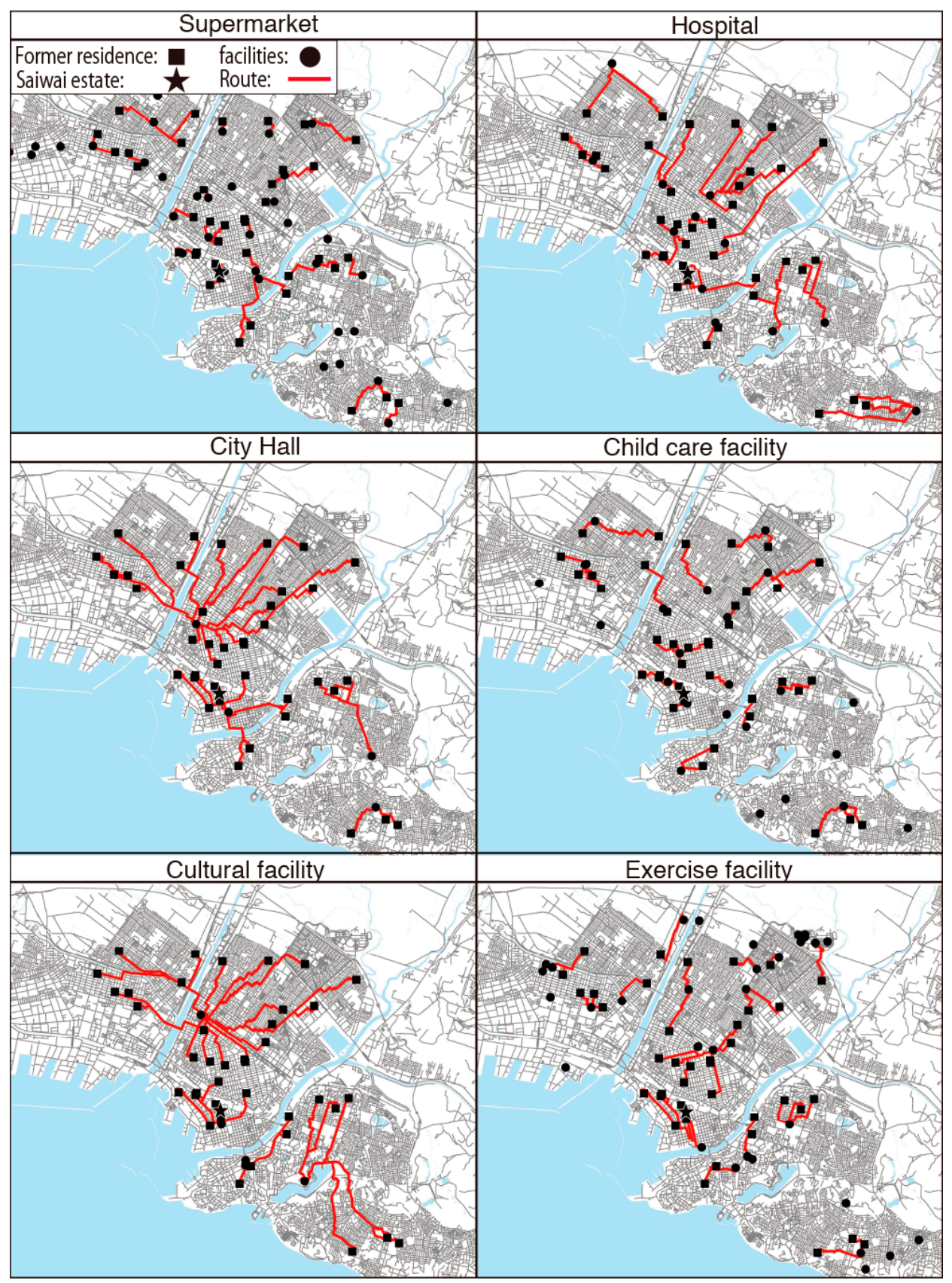

Figure 13. The changes in the distance to public facilities and gasoline costs caused by moving.

Table 2. The changes in the distance to public facilities and gasoline fee before and after the moving.

\begin{tabular}{|c|c|c|c|c|c|}
\hline Facility & & & Distance of One Way & Gasoline Cost/Year & Frequency \\
\hline \multirow{3}{*}{ Supermarket } & \multirow{3}{*}{ Average } & Before & $642 \mathrm{~m}$ & 16,854 yen & \multirow{3}{*}{ Twice/week } \\
\hline & & After & $164 \mathrm{~m}$ & 4305 yen & \\
\hline & & Changing & $-478 \mathrm{~m}$ & $-12,549$ yen & \\
\hline \multirow{3}{*}{ Hospital } & \multirow{3}{*}{ Average } & Before & $1260 \mathrm{~m}$ & 16,539 yen & \multirow{3}{*}{ Once/week } \\
\hline & & After & $689 \mathrm{~m}$ & 9044 yen & \\
\hline & & Changing & $-571 \mathrm{~m}$ & -7495 yen & \\
\hline
\end{tabular}


Table 2. Cont.

\begin{tabular}{|c|c|c|c|c|c|}
\hline Facility & & & Distance of One Way & Gasoline Cost/Year & Frequency \\
\hline \multirow{3}{*}{ City Hall } & \multirow{3}{*}{ Average } & Before & $1816 \mathrm{~m}$ & 11,919 yen & \multirow{3}{*}{ Twice/month } \\
\hline & & After & $562 \mathrm{~m}$ & 3688 yen & \\
\hline & & Changing & $-1254 \mathrm{~m}$ & -8230 yen & \\
\hline \multirow{3}{*}{ Child-rearing facility } & \multirow{3}{*}{ Average } & Before & $732 \mathrm{~m}$ & 22,511 yen & \multirow{3}{*}{ Fifth/week } \\
\hline & & After & $343 \mathrm{~m}$ & 48,042 yen & \\
\hline & & Changing & $-390 \mathrm{~m}$ & $-25,530$ yen & \\
\hline \multirow{3}{*}{ Cultural facility } & \multirow{3}{*}{ Average } & Before & $2004 \mathrm{~m}$ & 13,152 yen & \multirow{3}{*}{ Twice/month } \\
\hline & & After & $384 \mathrm{~m}$ & 2520 yen & \\
\hline & & Changing & $-1620 \mathrm{~m}$ & $-10,632$ yen & \\
\hline \multirow{3}{*}{ Exercise facility } & \multirow{3}{*}{ Average } & Before & $1001 \mathrm{~m}$ & 6570 yen & \multirow{3}{*}{ Twice/month } \\
\hline & & After & $1058 \mathrm{~m}$ & 6944 yen & \\
\hline & & Changing & $57 \mathrm{~m}$ & 374 yen & \\
\hline \multirow{3}{*}{ Elementary school } & \multirow{3}{*}{ Average } & Before & $591 \mathrm{~m}$ & 38,788 yen & \multirow{3}{*}{ Fifth/week } \\
\hline & & After & $573 \mathrm{~m}$ & 37,607 yen & \\
\hline & & Changing & $-20 \mathrm{~m}$ & -1181 yen & \\
\hline \multirow{3}{*}{ Middle school } & \multirow{3}{*}{ Average } & Before & $1045 \mathrm{~m}$ & 68,584 yen & \multirow{3}{*}{ Fifth/week } \\
\hline & & After & $1218 \mathrm{~m}$ & 79,939 yen & \\
\hline & & Changing & $190 \mathrm{~m}$ & 11,354 yen & \\
\hline \multirow{3}{*}{ Commuting } & \multirow{3}{*}{ Average } & Before & $2834 \mathrm{~m}$ & 186,019 yen & \multirow{3}{*}{ Fifth/week } \\
\hline & & After & $2466 \mathrm{~m}$ & 161,848 yen & \\
\hline & & Changing & $-368 m$ & $-24,171$ yen & \\
\hline
\end{tabular}

\section{3. [Survey B] Improvement of the Usability of the Estate as an Evacuation Facility}

Figure 14 shows the results of survey B. For "Recognition of Saiwai estate as an evacuation facility," more than $60 \%$ of the residents answered, "I know that it is an evacuation facility." For "candidates for evacuation destination," more than $60 \%$ of the residents cited public facilities, and few people cited private facilities such as hotels.

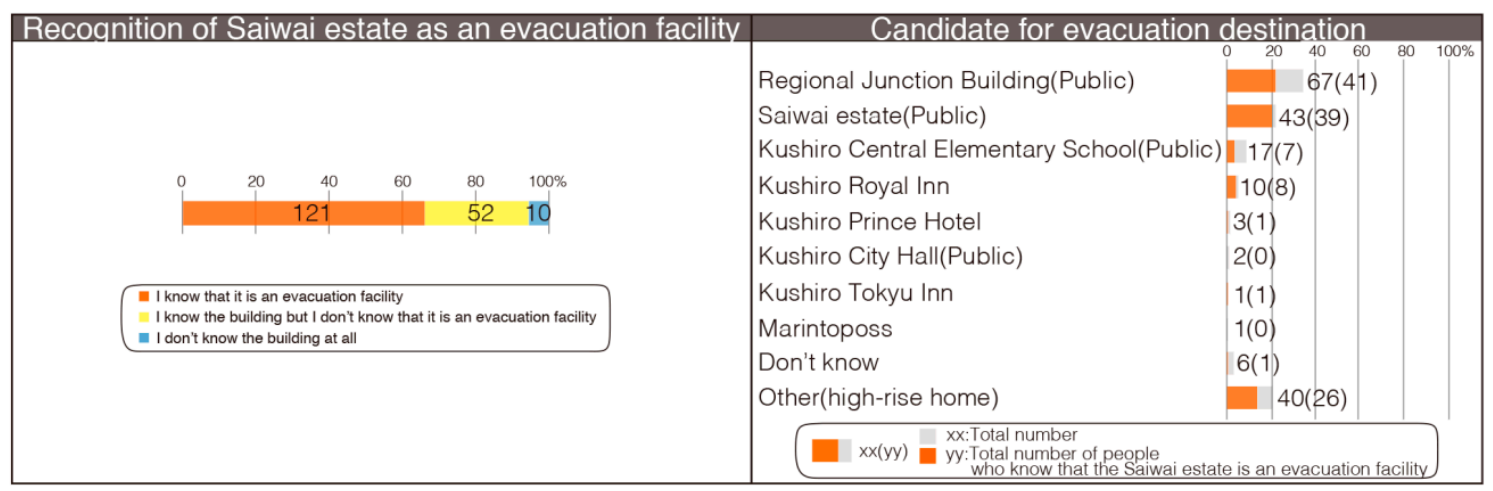

Figure 14. The questionnaire for surrounding residents on the evacuation against tsunamis.

\section{4. [Survey C] Reduction in Evacuation Distance Around the Saiwai Estate}

Figure 15 and Table 3 show the results of survey C. The shortest evacuation distance is reduced in the eight blocks, including the block where the Saiwai estate is located. The total population to experience a reduction in the evacuation distance is 948 people, and the evacuation distance is reduced by $157 \mathrm{~m}$ on average. This is a shortening of the evacuation time by about $3 \mathrm{~min}$ at a winter season walking speed. There are especially high reductions of more than $200 \mathrm{~m}$ in the evacuation distance for 
blocks No. 23 and No. 25, which each have a daytime population exceeding 100 people. There is a nursing home and a central post office in block No. 23, for which the evacuation distance is reduced by $240 \mathrm{~m}$. The reduction of the evacuation distance by $240 \mathrm{~m}$ has the effect of shortening the evacuation time of $8 \mathrm{~min}$ by $8.7 \mathrm{~min}$ when converting based on the walking speed of vulnerable people.

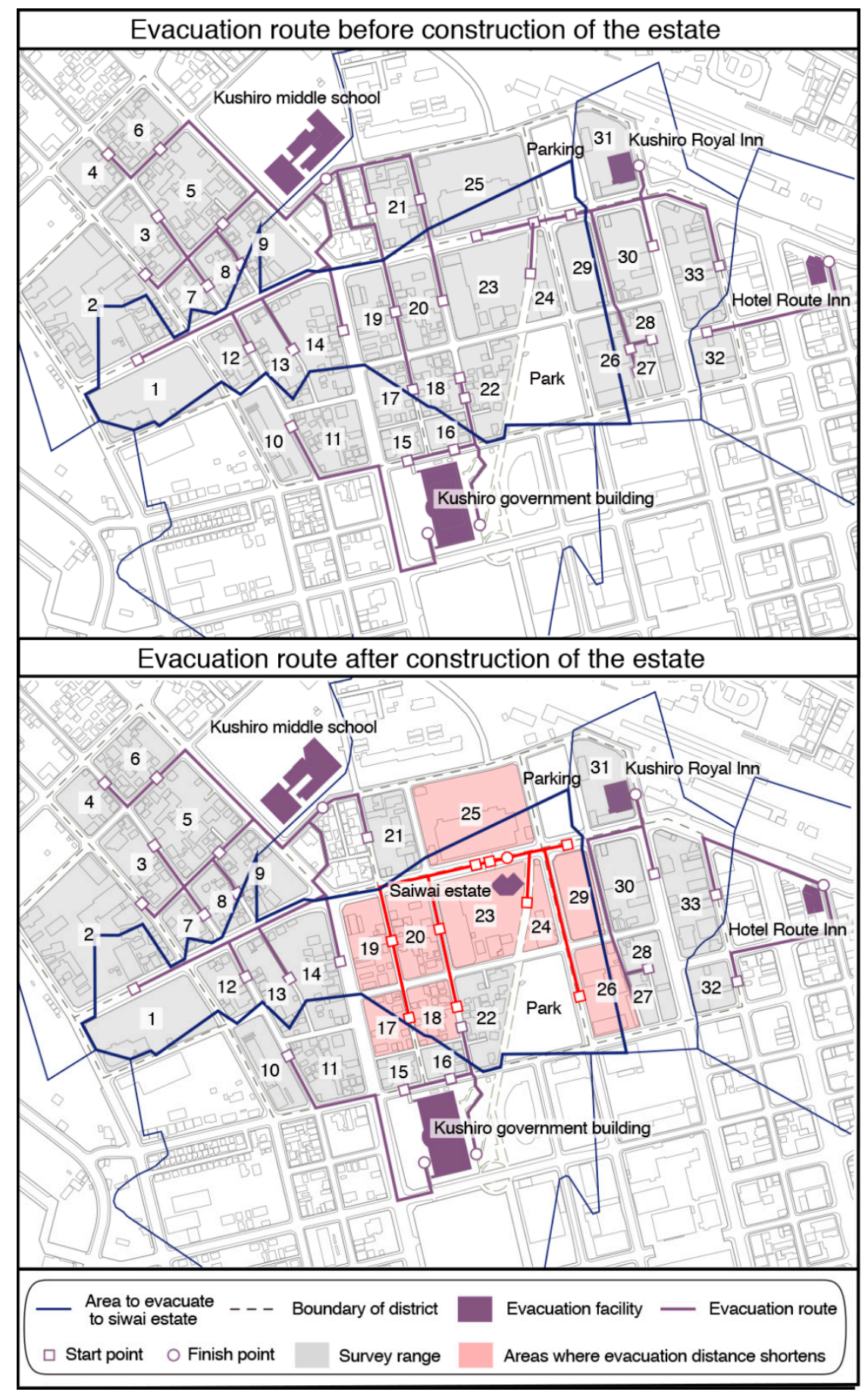

Figure 15. The reduction in the shortest evacuation distance around the Saiwai estate. 
Table 3. The changes in the shortest evacuation distance before and after the construction of the Saiwai estate.

\begin{tabular}{|c|c|c|c|c|}
\hline \multirow{2}{*}{ Block No. } & \multirow{2}{*}{ Daytime Population } & \multicolumn{3}{|c|}{ The Shortest Evacuation Distance } \\
\hline & & Before the Construction & After the Construction & Changing \\
\hline 1 & 8 & $504 \mathrm{~m}$ & $504 \mathrm{~m}$ & $0 \mathrm{~m}$ \\
\hline 2 & 101 & $430 \mathrm{~m}$ & $430 \mathrm{~m}$ & $0 \mathrm{~m}$ \\
\hline 3 & 16 & $293 \mathrm{~m}$ & $293 \mathrm{~m}$ & $0 \mathrm{~m}$ \\
\hline 4 & 9 & $389 \mathrm{~m}$ & $389 \mathrm{~m}$ & $0 \mathrm{~m}$ \\
\hline 5 & 52 & $187 \mathrm{~m}$ & $187 \mathrm{~m}$ & $0 \mathrm{~m}$ \\
\hline 6 & 31 & $360 \mathrm{~m}$ & $360 \mathrm{~m}$ & $0 \mathrm{~m}$ \\
\hline 7 & 11 & $267 \mathrm{~m}$ & $267 \mathrm{~m}$ & $0 \mathrm{~m}$ \\
\hline 8 & 12 & $223 \mathrm{~m}$ & $223 \mathrm{~m}$ & $0 \mathrm{~m}$ \\
\hline 9 & 32 & $201 \mathrm{~m}$ & $201 \mathrm{~m}$ & $0 \mathrm{~m}$ \\
\hline 10 & 110 & $372 \mathrm{~m}$ & $372 \mathrm{~m}$ & $0 \mathrm{~m}$ \\
\hline 11 & 37 & $336 \mathrm{~m}$ & $336 \mathrm{~m}$ & $0 \mathrm{~m}$ \\
\hline 12 & 18 & $307 \mathrm{~m}$ & $307 \mathrm{~m}$ & $0 \mathrm{~m}$ \\
\hline 13 & 14 & $433 \mathrm{~m}$ & $433 \mathrm{~m}$ & $0 \mathrm{~m}$ \\
\hline 14 & 27 & $407 \mathrm{~m}$ & $407 \mathrm{~m}$ & $0 \mathrm{~m}$ \\
\hline 15 & 33 & $357 \mathrm{~m}$ & $357 \mathrm{~m}$ & $0 \mathrm{~m}$ \\
\hline 16 & 10 & $322 \mathrm{~m}$ & $322 \mathrm{~m}$ & $0 \mathrm{~m}$ \\
\hline 17 & 17 & $340 \mathrm{~m}$ & $316 \mathrm{~m}$ & $24 \mathrm{~m}$ \\
\hline 18 & 20 & $328 \mathrm{~m}$ & $328 \mathrm{~m}$ & $0 \mathrm{~m}$ \\
\hline 19 & 36 & $235 \mathrm{~m}$ & $213 \mathrm{~m}$ & $22 \mathrm{~m}$ \\
\hline 20 & 88 & $246 \mathrm{~m}$ & $224 \mathrm{~m}$ & $22 \mathrm{~m}$ \\
\hline 21 & 19 & $124 \mathrm{~m}$ & $124 \mathrm{~m}$ & $0 \mathrm{~m}$ \\
\hline 22 & 34 & $314 \mathrm{~m}$ & $314 \mathrm{~m}$ & $0 \mathrm{~m}$ \\
\hline 23 & 380 & $260 \mathrm{~m}$ & $20 \mathrm{~m}$ & $240 \mathrm{~m}$ \\
\hline 24 & 19 & $263 \mathrm{~m}$ & $114 \mathrm{~m}$ & $149 \mathrm{~m}$ \\
\hline 25 & 175 & $246 \mathrm{~m}$ & $18 \mathrm{~m}$ & $228 \mathrm{~m}$ \\
\hline 26 & 83 & $292 \mathrm{~m}$ & $250 \mathrm{~m}$ & $42 \mathrm{~m}$ \\
\hline 27 & 22 & $291 \mathrm{~m}$ & $291 \mathrm{~m}$ & $0 \mathrm{~m}$ \\
\hline 28 & 39 & $318 \mathrm{~m}$ & $318 \mathrm{~m}$ & $0 \mathrm{~m}$ \\
\hline 29 & 150 & $141 \mathrm{~m}$ & $87 \mathrm{~m}$ & $54 \mathrm{~m}$ \\
\hline 30 & 370 & $182 \mathrm{~m}$ & $182 \mathrm{~m}$ & $0 \mathrm{~m}$ \\
\hline 31 & 197 & $171 \mathrm{~m}$ & $171 \mathrm{~m}$ & $0 \mathrm{~m}$ \\
\hline 32 & 33 & $216 \mathrm{~m}$ & $216 \mathrm{~m}$ & $0 \mathrm{~m}$ \\
\hline 33 & 139 & $183 \mathrm{~m}$ & $183 \mathrm{~m}$ & $0 \mathrm{~m}$ \\
\hline
\end{tabular}

\section{5. [Survey D-1] Questionnaire Survey for Residents of the Estate}

Figure 16 shows the results of survey D-1. Regarding whether they are "worried about tsunamis," more than $80 \%$ of residents responded "worried" or "a little worried." Regarding "reassurance about the threat of tsunami due to living in the Saiwai estate," more than $60 \%$ of residents responded "reassured" or "somewhat reassured." For "reassuring items regarding the Saiwai estate," "that it is designated as a tsunami emergency evacuation facility" is the most cited factor. For "worrying items regarding the Saiwai estate," "the evacuation of the surrounding residents" was the most cited issue.

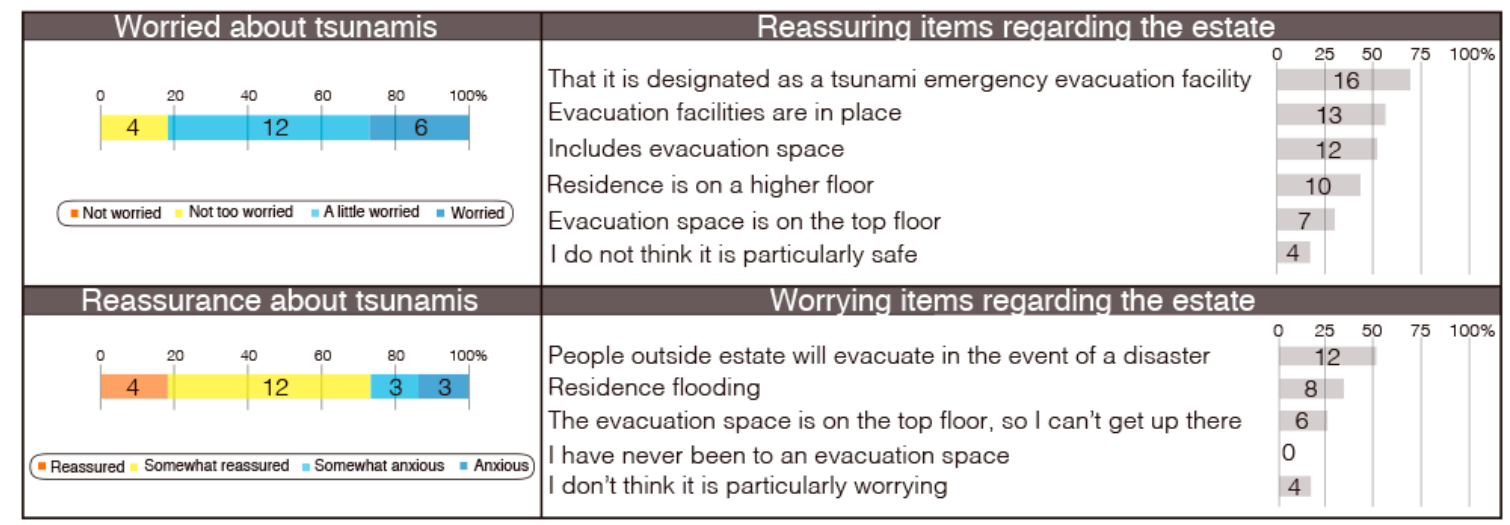

Figure 16. The questionnaire of residents on the evacuation against tsunamis. 


\section{6. [Survey D-2] Questionnaire Survey for Residents Surrounding the Estate}

Figure 17 shows the results of survey D-2. For "concern about the damage caused by the tsunami," about $80 \%$ of the surrounding residents answered "worried" or "a little worried". A total of $80 \%$ of the surrounding residents responded with "reassured" or "somewhat reassured" to "reassurance about the threat of tsunami due to the construction of the Saiwai estate," and about $80 \%$ of that number live in a block where there has been a decrease in the shortest evacuation distance. In other words, about $20 \%$ of the residents who answered that they feel reassured regarding tsunamis did so despite a lack of a decrease in their evacuation distance. For "reassuring items regarding the estate," more than half of the residents answered, "it is nearby, and I can evacuate immediately." Additionally, about $30 \%$ of residents answered, "Evacuation space in on the top floor" For "worrying items regarding the estate," $60 \%$ of residents answered, "evacuation space will be full in the event of a disaster." For "candidates for evacuation destination," more than $60 \%$ of the residents cited public facilities, and few people cited private facilities such as hotels.

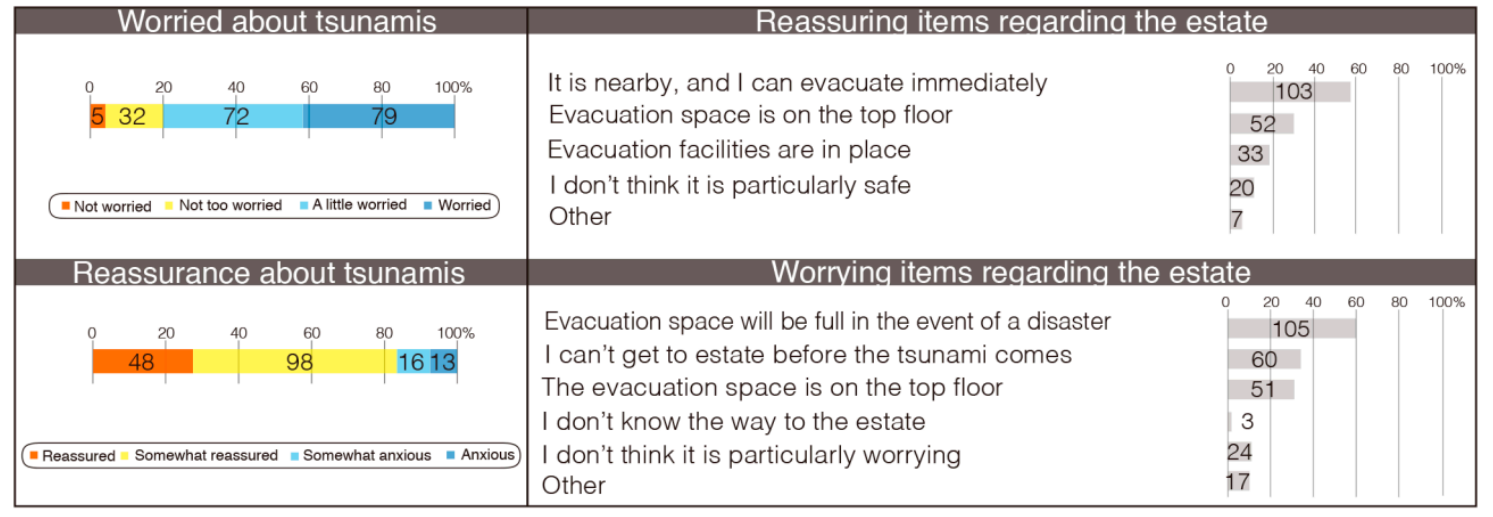

Figure 17. The questionnaire for surrounding residents about tsunami evacuation.

\section{Discussion}

[Survey A-1] clarifies that moving has provided the residents with a more convenient surrounding environment and that they are more satisfied with the surrounding environment than they were before moving. The high degree of resident satisfaction with a surrounding environment that has a high level of perceived convenience support the findings of previous studies [44,45], confirming the positive impact of the accessibility to surrounding facilities on residents' satisfaction. The results of [Survey A-2] show that the travel distance to public facilities has actually shortened and the travel costs have reduced after moving. These reductions in travel distance and costs due to moving to a downtown area are consistent with a previous study [50] that confirmed that there is high accessibility in the downtown area and a resulting low cost of movement. These survey results suggest that the downtown area is more convenient than suburban high-rises that offer a high level of safety against tsunamis, making the residents satisfied with the surrounding environment. On the other hand, by moving to the downtown area, residents now live in areas where potential flooding is deeper than before they moved. According to the questionnaire survey on tsunami evacuation [Survey D-1], many residents feel anxious about tsunami hazards due to living in the downtown area. However, it can be seen that living in an estate with tsunami evacuation facilities improves the responding residents' sense of security. Thus, the inclusion of a tsunami evacuation facility in public housing in the downtown area improves both the living convenience and the reassurance of the residents of the estate with regards to the threat of tsunamis. This project realizes both the introduction of residence and public facilities to the downtown area for the promotion of downtown living and the inclusion of a tsunami evacuation facility with sufficient structural reinforcement and equipment to improve the tsunami evacuation performance in the downtown area. This shows, for the first time, the effect of dealing 
with the promotion of downtown living and the improvement of tsunami evacuation performance in parallel to facilitate downtown revitalization in regional coastal cities.

The questionnaire about the attitudes of the surrounding residents towards tsunami evacuation (Survey B) shows that they tend to evacuate to public evacuation facilities. From this, it is understood that, in the event of a disaster, residents tend to evacuate to facilities that are available on a daily basis and that are familiar to them. This influence of recognition by routine use on the selection of an evacuation destination supports a previous study [51] that revealed the tendency of evacuees to select facilities that they are highly aware on a daily basis. Furthermore, the current research has made it clear that it is not important to residents whether facilities are designated as evacuation facilities. For this reason, even if private facilities such as hotels and condominiums were to be designated as evacuation facilities like the tsunami evacuation buildings in Kushiro city, there is a possibility that they would not be used in the event of a disaster. Thus, there is a danger of the saturation of the evacuation space due to the concentration of refugees converging on public evacuation facilities and a prolongation of the evacuation distances of evacuees who do not use the closest evacuation facility. Research has been carried out previously on the evacuation possibilities in existing buildings in Kushiro city [47,48]. However, there have been no descriptions of the tendencies of residents to select particular evacuation destinations. There is a policy to promote public awareness of evacuation facilities on a daily basis by utilizing such places for public functions such as childcare in the Saiwai estate. When setting up an evacuation facility, the promotion of its daily use and raising the neighboring residents' awareness that it is an evacuation facility increase the usability of the evacuation facility in the event of a disaster. Therefore, it is necessary for local governments to install public functions in tsunami evacuation facilities and make them available to the neighborhood on a daily basis to improve awareness.

The questionnaire survey on tsunami evacuation (Survey D-2) indicates that the construction of a high-rise estate with a tsunami evacuation facility on the upper floors improves the reassurance of not only the residents of the estate but also the surrounding residents about the threat of tsunamis. The GIS analysis of the tsunami evacuation distance (Survey C) further shows that the construction of the estate with its tsunami evacuation facility reduces the shortest evacuation distance of many surrounding residents. Some of the surrounding residents feel reassured regarding tsunamis even though their shortest evacuation distance has not reduced. It can be seen that there is both a direct improvement effect on the reassurance regarding tsunamis when accompanied by a reduction in the evacuation distance and an indirect improvement effect on it when the construction of the estate causes no reduction in the evacuation distance. From the above, it can be seen that the construction of high-rise public housing incorporating tsunami evacuation facilities on the upper floors to the downtown area contributes to the improvement of tsunami evacuation performance in the surrounding urban areas. In other words, installing a public facility in public housing that addresses the problems of the surrounding urban area improves the living environment of those surrounding areas. Municipalities need to improve the living environment of the community by considering public housing not as a simple housing supply but as a tool for solving the problems of the community and installing public facilities in public housing that correspond to community problems. At first glance, the installation of a public facility seems to be excessive for public housing, but this is not necessarily so, as the residents around the estate also enjoy the benefits of the public facility. In addition, there is a possibility that interaction between residents of the public housing and neighboring residents will be fostered through the use of this public facility. Further investigation of this possibility is necessary. It has been revealed that interaction with neighboring residents has a positive influence on the level of resident satisfaction with living arrangements, especially for low-income residents [52-54]. However, problems can arise with the installation of public facilities. It was originally planned that the evacuation space in the Saiwai estate would be used as a childcare facility on a daily basis. However, as of 2016 when this survey was carried out, this had not been initiated due to insufficient staff availability. At the time of planning, there was a policy to set up a non-profit organization (NPO) to manage such facilities, centering on officials in the local government. However, the municipality could not launch an NPO 
because of the problems associated with responsibility for injuries to children when such a facility is operated by citizens without childcare qualifications. This situation indicates that it is necessary to consider and organize the entities that operate the public facility from the planning stage when installing a public facility in public housing.

\section{Conclusions}

This research article has investigated the effect of dealing with the promotion of downtown living and the improvement of tsunami evacuation performance in parallel by evaluating the Saiwai estate program in Kushiro city, Hokkaido, Japan. In this chapter, we show the effects due to dealing with the above two tasks in parallel. In Sections 5.1 and 5.2, the effects of this project, as clarified by evaluation, are organized on the basis of two methodical viewpoints (placing public housing with a public facility in the downtown area and installing a tsunami evacuation facility in the public housing area). In chapter 5.3, the effects of this project, as clarified by evaluation, are organized on the basis of two evaluation viewpoints (the effects on the promotion of downtown living and the improvement of tsunami evacuation performance).

\subsection{The Effects of Relocating Public Housing with a Public Facility to the Downtown Area [Survey A-1]} [Survey A-2] [Survey B]

- Building public housing in the downtown area induces a population shift from suburban areas to the downtown area.

- On the other hand, residents living in downtown areas near the coast face a higher tsunami risk.

- By placing public housing in the downtown area, the satisfaction of the residents and the convenience of the surrounding environment are improved compared to before moving.

- Building public housing in the downtown area could reduce the distance to public facilities compared to before moving.

- Installing a tsunami evacuation facility in a public facility that is open to the neighborhood can improve the function of the evacuation facility at the time of disaster.

\subsection{The Effects of Installing an Evacuation Facility in the Estate [Survey C] [Survey D-1] [Survey D-2]}

- Constructing public housing with tsunami evacuation facilities in the downtown area of a coastal city can reduce the shortest evacuation distances of the surrounding residents.

- Installing a tsunami evacuation facility in on the upper floors of a high-rise public housing building can improve the reassurance of the residents in and around the public housing area with regards to the threat of tsunamis.

\subsection{The Effects of Dealing with the Promotion of Downtown Living and the Improvement of Tsunami Evacuation Performance in Parallel for Downtown Revitalization}

In this chapter, the effects of this project, as clarified by evaluation, are organized on the basis of the viewpoints of evaluation: the effects on the promotion of downtown living and the effects on the improvement of tsunami evacuation performance. The effect on the promotion of downtown living due to relocating high-rise public housing with tsunami evacuation facilities to the downtown area is an improvement of both the convenience of everyday life and the reassurance of the residents in the estate regarding tsunamis. Both of these improvements contribute to reducing the uneasiness that can be a hurdle that discourages people from moving to the downtown areas of regional coastal cities. These investigations have clarified the synergistic effect between the promotion of downtown living and the improvement of tsunami evacuation performance in the downtown area. Therefore, dealing with the promotion of downtown living and the improvement of tsunami evacuation performance in parallel contribute to realizing downtown revitalization in regional coastal cities, and the relocation of high-rise public housing with tsunami evacuation facilities in the downtown area can be an important means to that end. 
In addition, two strategies are required to secure the synergistic effect between the promotion of downtown living and the improvement of tsunami performance. First is installing a tsunami evacuation facility in a public facility that is open to the neighborhood, such as child-rearing support facilities or day care centers. This strategy improves its recognition as an evacuation facility by the surrounding residents, securing the usability of the tsunami evacuation facilities. From the viewpoints of evaluation - the effects on the improvement of tsunami evacuation performance-it is clear that public housing with a tsunami evacuation facility installed in public facilities realizes both the improvement of the usability of the evacuation facility in the event of a disaster and the reduction of the shortest evacuation distance. The abovementioned two realizations are a synergistic effect of the promotion of downtown living and the improvement of tsunami evacuation performance, which leads to the improvement of tsunami evacuation performance. Second is the development of high-rise housing in which tsunami evacuation facilities are installed on the upper floors with public and private partnership. This strategy helps local governments to develop a lot of high-rise housing within which they install tsunami evacuation facilities with a smaller financial burden. The government is required to develop both public and private high-rise housing and subsidize the installation of the tsunami evacuation facility on the upper floors of the high-rise buildings. Supplying public and private housing actively with public facilities to the downtown area can be expected to promote the recovery of the population in the downtown area, thereby leading to downtown revitalization. In addition, installing tsunami evacuation facilities in public and private housing contributes to downtown revitalization due to the synergistic effect. Thus, the development of high-rise housing by installing tsunami evacuation facilities on the upper floors with public and private partnership effectively contributes to downtown revitalization.

Thus, we show that planning the downtown revitalization and disaster prevention in parallel, which had been separately planned so far, is a fundamental approach for urban revitalization corresponding to both normal situations and emergencies in regional coastal cities. Improving the daily living environment through means such as downtown revitalization and building emergency urban environments through disaster prevention together toward urban revitalization is not only important for coastal cities where there is a danger from tsunamis but is also important for all cities at risk from large-scale disasters such as floods, cliff collapses, or earthquakes. Therefore, the findings of this research contribute to the sustainable development of every city where there is a high level of disaster risk.

Author Contributions: Formal analysis, T.I.; A.I.; investigation, T.I.; resources, T.M.; writing—original draft preparation, T.I.; writing-review and editing, N.W.; supervision, T.S.

Funding: This research received no external funding.

Acknowledgments: This work was supported by JSPS KAKENHI Grant Number 26630269.

Conflicts of Interest: The authors declare no conflict of interest.

\section{References}

1. Japan's Future Population. Available online: http://www.ipss.go.jp/pp-zenkoku/j/zenkoku2017/pp29_ gaiyou.pdf (accessed on 6 November 2018).

2. Sakamoto, K.; Iida, A.; Yokohari, M. Spatial patterns of population turnover in a Japanese Regional City for urban regeneration against population decline: Is Compact City policy effective? Cities 2018, 81, 230-241. [CrossRef]

3. Population Vision in Hokkaido. Available online: http://www.pref.hokkaido.lg.jp/ss/csr/ksk/jinkou/ kyogikai/3_shiryo3.pdf (accessed on 6 November 2018).

4. Gumma, M.K.; Mohammad, I.; Nedumaran, S.; Whitbread, A.; Lagerkvist, C.J. Urban Sprawl and Adverse Impacts on Agricultural Land: A Case Study on Hyderabad, India. Remote Sens. 2017, 9, 1136. [CrossRef]

5. Li, X.; Yang, L.; Ren, Y.; Li, H.; Wang, Z. Impacts of Urban Sprawl on Soil Resources in the Changchun-Jilin Economic Zone, China, 2000-2015. Int. J. Environ. Res. Public Health 2018, 15, 1186. [CrossRef] [PubMed] 
6. Ala-Mantila, S.; Heinonen, J.; Junnila, S. Greenhouse Gas Implications of Urban Sprawl in the Helsinki Metropolitan Area. Sustainability 2013, 5, 4461-4478. [CrossRef]

7. Li, K.-Q.; Lu, R.; Chu, R.-W.; Ma, D.-D.; Zhu, L.-Q. Trends and Driving Forces of Carbon Emissions from Energy Consumption: A Case Study of Nanjing, China. Sustainability 2018, 10, 4348. [CrossRef]

8. Bo, C.; Xu, H.; Liu, Y. Examination of the Relationships between Urban Form and Urban Public Services Expenditure in China. Adm. Sci. 2017, 7, 39.

9. Zolnik, E.J. The costs of sprawl for private-vehicle commuters. J. Transp. Geogr. 2012, 20, 23-30. [CrossRef]

10. Setoguchi, T.; Nagao, M.; Okabe, Y.; Oinuma, T.; Matsumura, H. The development of future city images based on the citizen's demands for intensive compact cities. The planning approaches for downsizing of city area on Yubari city master plan. Trans. Archit. Inst. Jpn. J. Archit. Plan. Environ. Eng. 2014, 79, 949-958.

11. Wang, H.J.; Lee, H.Y. How government-funded projects have revitalized historic streetscapes-Two cases in Taiwan. Cities 2008, 25, 197-206. [CrossRef]

12. Balsas, C.J.L.; Robertson, K.A. Can small-city downtowns remain viable?: City center revitalization in Portugal. JAPA 1999, 65, 270-283.

13. Spader, J.; Schuetz, J.; Cortes, A. Fewer vacants, fewer crimes? Impacts of neighborhood revitalization policies on crime. Reg. Sci. Urban Econ. 2016, 60, 73-84. [CrossRef]

14. Tamura, S.; Iwamoto, S.; Tanaka, T. The impact of spatial population distribution patterns on $\mathrm{CO}_{2}$ emissions and infrastructure costs in a small Japanese town. SCS 2018, 40, 513-523.

15. Takayuki, K.; Higuchi, S.; Nakade, B.; Matsukawa, T. Study on Relationship between Fixed Property Tax Revenue and Building Activity in Local Cities-A Case Study of Three Non-Area Divided Cities, Ueda City, Ise City and Okinawa City. J. City Plan. Inst. Jpn. 2015, 50, 879-885.

16. Country Grand Design 2050. Available online: http://www.mlit.go.jp/common/001047113.pdf (accessed on 7 November 2018).

17. Doratli, N. Revitalizing historic urban quarters: A model for determining the most relevant strategic approach. Eur. Plan. Stud. 2005, 13, 749-772. [CrossRef]

18. Park, C. Lessons of downtown revitalization plans in Korea. Urban Policy Res. 2004, 22, 447-463. [CrossRef]

19. Osman, K.A.; Farahat, B.I. The conservation of the waterfront of Saida: A model for tourism and culture-led revitalization in valuable areas. HBRC J. 2018, 14, 321-333. [CrossRef]

20. Vukonic, B.; Tkalack, D. Tourism and Urban Revitalization: A Case Study of Pore\& Yugoslavia. Ann. Tour. Res. 1984, 11, 591-605.

21. Miyauchi, T.; Setoguchi, T.; Kitahara, K.; Nakata, H.; Ito, T. Quantitative evaluations of the downtown habitation programs with public housing redevelopments toward the consolidated compact cities. Trans. Archit. Inst. Jpn. J. Archit. Plan. Environ. Eng. 2018, 83, 1025-1035. [CrossRef]

22. Galster, C.G.; Hesser, W.G. Residential satisfaction: Compositional and contextual correlates. Environ. Behav. 1981, 13, 735-758. [CrossRef]

23. Riazi, M.; Emami, A. Residential satisfaction in affordable housing: A mixed method study. Cities 2018, 82, 1-9. [CrossRef]

24. Mu, S. Community Building in Social-Mix Public Housing: Participatory planning of Ankang redevelopment plan. Behav. Soc. Sci. Libr. 2016, 222, 755-762. [CrossRef]

25. Morris, A.; Jamieson, M.; Patulny, R. Is social mixing of tenures a solution for public housing estates. Evid. Base 2012, 1, 1-21.

26. Tam, V.W.Y.; Fung, I.W.H.; Tsang, Y.T.; Chan, L. Development of a Universal Design-Based Guide for Handrails: An Empirical Study for Hong Kong Elderly. Sustainability 2018, 10, 4233. [CrossRef]

27. Economic and Fiscal Effects of Consolidation and Declaration of Public Facilities etc. Available online: https:/ / www5.cao.go.jp/keizai3/2016/08seisakukadai09-0.pdf (accessed on 10 November 2018).

28. Child-rearing Support Housing Promotion Policy in Hokkaido. Available online: http:/ /www.pref.hokkaido. lg.jp/kn/jtk/grp/100915-3kosodatepamph.pdf (accessed on 10 November 2018).

29. Tomita, T.; Imamura, F.; Arakawa, T.; Yasuda, T.; Kawata, Y. Damage caused by the 2004 Indian Ocean Tsunami on the southwestern coast of Sri Lanka. Coast. Eng. J. 2006, 48, 99-116. [CrossRef]

30. Mori, N.; Takahashi, T.; Yasuda, T.; Yanagisawa, H. Survey of 2011 Tohoku earthquake tsunami inundation and run-up. Geophys. Res. Lett. 2011, 38. [CrossRef] 
31. Goto, K.; Ikehara, K.; Goff, J.; Chague-Goff, C.; Jaffe, B. The 2011 Tohoku-oki tsunami-Three years on. Mar. Geol. 2014, 358, 2-11. [CrossRef]

32. Sun, Y.; Yamori, K. Risk Management and Technology: Case Studies of Tsunami Evacuation Drills in Japan. Sustainability 2018, 10, 2982. [CrossRef]

33. Lee, S.W.; Song, D.W.; Ducruet, C. A tale of Asia's world ports: The spatial evolution in global hub port cities. Geoforum 2008, 39, 372-385. [CrossRef]

34. Ishii, A.; Suzuki, H.; Setoguchi, T. Residential land supply methods to develop a housing reconstruction scenario in a large tsunami-devastated area: Time series analysis of residential land supply based on building GIS database after the Great East Japan Earthquake in Rikuzentakata city, Iwate. Trans. Archit. Inst. Jpn. J. Archit. Plan. Environ. Eng. 2018, 83, 1273-1283.

35. Sina, D.; Chang-Richards, A.Y.; Wilkinson, S.; Potangaroa, R. What does the future hold for relocated communities post-disaster? Factors affecting livelihood resilience. Int. J. Dis. Risk Reduct. 2018. [CrossRef]

36. Dall'Osso, F.; Dominey-Howes, D. Public assessment of the usefulness of "draft" tsunami evacuation maps from Sydney, Australia-implications for the establishment of formal evacuation plans. Nat. Hazards Earth Syst. 2010, 10, 1739-1750. [CrossRef]

37. Wegscheider, S.; Post, J.; Zosseder, K.; Muck, M.; Strunz, G.; Riedlinger, T.; Muhari, A.; Anwar, Z.H. Generating tsunami risk knowledge at community level as a base for planning and implementation of risk reduction strategies. Nat. Hazards Earth Syst. 2011, 11, 249-258. [CrossRef]

38. Chock, G.; Butler, R. Evacuation planning considerations of the city of Honolulu for a Great Aleutian Tsunami. In Proceedings of the Tenth U.S. National Conference on Earthquake Engineerin, Frontiers of Earthquake Engineerin, Anchorage, AK, USA, 21-25 July 2014.

39. Goseberg, N.; Schlurmann, T. Non-stationary flow around buildings during run-up of tsunami waves on a plain beach. Coast. Eng. 2014, 34. [CrossRef]

40. Scheer, J.S.; Varela, V.; Eftychidis, G. A generic framework for tsunami evacuation planning. Phys. Chem. Earth 2012, 49, 79-91. [CrossRef]

41. Suppasri, A.; Shuto, N.; Imamura, F.; Koshimura, S.; Mas, E.; Yalciner, C.A. Lessons learned from the 2011 great east japan tsunami: Performance of tsunami countermeasures, coastal buildings, and tsunami evacuation in Japan. Pure Appl. Geophys. 2013, 170, 993-1018. [CrossRef]

42. Ogawa, M.; Tsuboi, S.; Kuroyanagi, A. Research on designation and management of tsunami evacuation building. Pap. Environ. Inf. Sci. 2012, 26, 289-294.

43. Specified Number of Tsunami Evacuation Building by Prefecture. Available online: http://www.mlit.go.jp/ common/000186681.pdf (accessed on 12 November 2018).

44. Mohit, A.M.; Ibrahim, M.; Rashid, R.Y. Assessment of residential satisfaction in newly designed public low-cost housing in Kuala Lumpur, Malaysia. Habitat Int. 2010, 34, 18-27. [CrossRef]

45. Tao, Z.; Cheng, Y.; Dai, T. Measuring spatial accessibility to residential care facilities in Beijing. Popul. Health Geogr. 2014, 33, 616-624.

46. Tsunami Evacuation Plan in Kushiro City. Available online: https://www.city.kushiro.lg.jp/common/ 000126473.pdf (accessed on 13 November 2018).

47. Miyamori, Y.; Uchiumi, K.; Shimizu, T.; Yamasaki, S.; Otsuka, H. A basic study of tsunami evacuation to shelter buildings and civil structures in Kushiro City. Editorial Comm. J. Jpn. Soc. Civ. Eng. (Struct./Earthq. Eng.) 2013, 69, 919-931.

48. Saito, T.; Muramoto, H.; Shimizu, T.; Miyamori, Y. A study of tsunami evacuation with consideration for damage to tall buildings in Kushiro City. J. Soc. Saf. Sci. 2014, 24, 151-159.

49. Kawakami, T.; Asano, M. A study on the sense of security that a disaster measure gives to citizens. J. City Plan. Inst. Jpn. 2001, 36, 409-414.

50. Dewita, Y.; Barbara, T.H.Y.; Burke, M. The effect of transport cost on housing affordability: Experiences from the T Bandung Metropolitan Area, Indonesia. Land Use Policy 2018, 79, 507-519. [CrossRef]

51. Nishimura, H.; Kurimata, K.; Iwasaki, Y.; Yamaguchi, Y. A study on the recognition and selection factors of the evacuation destination and evacuation route against the tsunami disaster. Proc. City Plan. Inst. Jpn. Kansai Branch 2012, 10, 73-76. 
52. Zhigang, L.; Fulong, W. Residential satisfaction in China's informal settlements: A case study of Beijing, Shanghai, and Guangzhou. Urban Geogr. 2013, 34, 923-949.

53. Chaskin, J.R.; Joseph, L.M. Social interaction in mixed-income developments: Relational expectations and emerging reality. Urban Aff. A 2011, 35, 423-431. [CrossRef]

54. Parkes, A.; Kearns, A.; Atkinson, R. What makes people dissatisfied with their neighborhoods? Urban Stud. 2002, 39, 2413-2438. [CrossRef]

2019 by the authors. Licensee MDPI, Basel, Switzerland. This article is an open access article distributed under the terms and conditions of the Creative Commons Attribution (CC BY) license (http://creativecommons.org/licenses/by/4.0/). 